\title{
COVID-19: Virus or Viral Conspiracy Theories?
}

\author{
Ghada M Abaido* and Aseel A Takshe \\ Department of Environmental Health Sciences \\ Faculty of Communication, Arts and Sciences, Canadian University Dubai UAE
}

*Corresponding author: Ghada M Abaido, Department of Communication, Arts and Sciences, Canadian University of Dubai, UAE. To Cite This Article: Ghada M Abaido and Aseel A Takshe, COVID-19: Virus or Viral Conspiracy Theories?. 2020 - 8(2). AJBSR.MS.ID.001252. DOI: 10.34297/AJBSR.2020.08.001252.

Received: 制 March 10, 2020; Published: 制 March 16, 2020

\begin{abstract}
A novel coronavirus called SARS-CoV2 has attracted considerable attention in the past three months, unlike its sisters the Middle East Respiratory Syndrome (MERS) and Severe Acute Respiratory Syndrome (SARS), and the disease it causes has been termed "coronavirus disease 2019" (COVID-19). The mortality rate of COVID-19, however, is lesser than that of SARS and MERS. Then why does COVID-19 seem to be a scarier pandemic than any before? Is it a serious virus outbreak or a sort of violence that has perpetrated across communities? The outbreak of the virus itself feels like it's happening in your own home. This article attempts to understand the reasons for the widespread attention received by COVID-19. To do so, it briefly presents what is known so far about the SARS-CoV2 virus. After that, it explores whether the media has played a role in the widespread and perhaps exaggerated attention directed at COVID-19. At the dawn of 2020, several pneumonia cases were reported in the city of Wuhan, China, that were caused by a novel coronavirus.
\end{abstract}

\section{Introduction}

According to the World Health Organization (WHO) [1], the virus quickly spread to more than 101 countries, infecting 110,000 people and killing 3,853. In general, coronaviruses $(\mathrm{CoV})$ are a large family of viruses that cause flu in humans. Toward the end of 2019, a novel strain of the coronavirus family called SARS-CoV2 was found to infect humans [2]. It is worth noting that coronaviruses are zoonotic, meaning they are transmitted from animals to people [3]. SARS and MERS have also been proven to be zoonotic. The current indications show that SARS-CoV2 is transmitted through bats mainly. These viruses pose threats to the human respiratory system, and thus, people with lung damage or respiratory problems are more susceptible to being infected by these viruses. Between 2003 and 2004, SARS killed nearly $10 \%$ of the 8,096 infected people in 29 countries [4]. A total of 774 people died according to the WHO [5]. MERS was considered more deadly, claiming the lives of about $34 \%$ of the infected people [6].

Table 1: Adapted from the data of WHO and US Centers for Disease Control and Prevention, compares different strains of coronaviruses. Comparison of Different Coronavirus Strains.

\begin{tabular}{|c|c|c|c|c|}
\hline & $\begin{array}{c}\text { COVID-19 } \\
\text { (SARS-Cov2) }\end{array}$ & $\begin{array}{l}\text { Middle East Respiratory } \\
\text { Syndrome (MERS) }\end{array}$ & $\begin{array}{l}\text { Severe Acute Respira- } \\
\text { tory Syndrome (SARS) }\end{array}$ & $\begin{array}{c}\text { Common Cold Caused by } \\
\text { Coronavirus }\end{array}$ \\
\hline Origin & First reported in China in 2019 & $\begin{array}{l}\text { Started in } 2012 \text { with the } \\
\text { first case being reported in } \\
\text { the KSA }\end{array}$ & $\begin{array}{l}\text { Started in } 2002 \text { with the } \\
\text { first case being reported } \\
\text { in China }\end{array}$ & $\begin{array}{c}\text { Up to } 30 \% \text { of common colds } \\
\text { are caused by different coro- } \\
\text { navirus strains }\end{array}$ \\
\hline Transmission & $\begin{array}{l}\text { Most probably from touching/eating infect- } \\
\text { ed animals. } \\
\text { Human-to-human infection caused by close } \\
\text { contact }\end{array}$ & $\begin{array}{l}\text { Proved to be from touching } \\
\text { infected camels or con- } \\
\text { suming their milk or meat } \\
\text { Human-to-human infection } \\
\text { due to close contact is } \\
\text { limited. }\end{array}$ & $\begin{array}{l}\text { Proved to have spread } \\
\text { from infected bats } \\
\text { Human-to-human } \\
\text { infection caused by close } \\
\text { contact }\end{array}$ & $\begin{array}{l}\text { Due to close contact with } \\
\text { infected humans or contami- } \\
\text { nated surfaces }\end{array}$ \\
\hline
\end{tabular}




\begin{tabular}{|c|c|c|c|c|}
\hline Cases & $\begin{array}{c}\text { Approximately 105,000 cases confirmed; } \\
\text { nearly 38,583 deaths as of March 2020; most } \\
\text { victims had pre-existing conditions }\end{array}$ & $\begin{array}{c}\text { Approximately 2,494 } \\
\text { confirmed cases; nearly } \\
858 \text { deaths }\end{array}$ & $\begin{array}{c}\text { Approximately 8,096 } \\
\text { cases confirmed: nearly } \\
774 \text { deaths }\end{array}$ & $\begin{array}{c}\text { Millions yearly; most cases are } \\
\text { not fatal unless pre-existing } \\
\text { conditions are present. }\end{array}$ \\
\hline $\begin{array}{c}\text { Current } \\
\text { Status }\end{array}$ & $\begin{array}{c}\text { Cases reported worldwide in more than 100 } \\
\text { countries }\end{array}$ & $\begin{array}{c}\text { Arabian Peninsula is the } \\
\text { source of all cases, mainly } \\
\text { the KSA. } \\
\text { Death rates have been } \\
\text { declining since 2016. }\end{array}$ & $\begin{array}{c}\text { Declined completely in } \\
2004\end{array}$ & $\begin{array}{c}\text { All throughout the year, every- } \\
\text { where, but mostly during the } \\
\text { winter season }\end{array}$ \\
\hline
\end{tabular}

Furthermore, unlike SARS, MERS outbreaks are still simmering. Since 2012, 2,494 confirmed cases of MERS have been reported in 27 countries, with 858 people being killed by the virus [6]. To date, SARS-CoV2 seems to be less virulent, with a $4 \%$ mortality rate $[1,7]$. although SARS-CoV2 is relatively new compared to SARS and MERS, information on this virus is more abundant. Social media has been widely discussing COVID-19 caused by this novel coronavirus much more than SARS or MERS. Traditional media, social media, and other information sources have also been discussing SARS-CoV2 in more detail and depth. Table 1, adapted from the data of WHO and US Centers for Disease Control and Prevention, compares different strains of coronaviruses.

Table 1 adapted from the data of WHO and US Centers for Disease Control and Prevention, compares different strains of coronaviruses. The main concern pertaining to SARS-CoV2 is that no treatment or vaccine has been found for it yet. However, this is not the case with influenza. Moreover, indications exist that COVID-19 might be more contagious than normal influenza [8]. Given the current epidemic and limited understanding of the epidemiology of COVID-19, understanding why the disease has created widespread panic and brought our day-to-day activities to a halt is important.

\section{Opinion}

Since the COVID-19 outbreak in late December 2019, stock markets have plummeted, tourism sectors have been affected, and videos of panic buying across the globe have been circulating on social media platforms. Media scholars can compare this scenario with the infamous 1938 "War of the Worlds" radio hoax broadcast by Orson Wells that resulted in mass hysteria in the United States of America [9]. The powerful effect of mass media as it emerged from the late 1800s to the 1940s, theorizing the "magic bullet" approach to understand the influence of mass media, seems to still exist on social media platforms and not outdated as many claim it to be. Mass manipulation can also still be performed but by now using advanced technological tools. Previous research (Oliver \& Wood, 2014) identified the tendency of conspiracy theories to arise during times of crisis, such as periods of political instability, economic threats, and public health crises, creating even more chaos. The same is applicable to virus outbreaks, as was the case with the 2015-16 Zika virus outbreak. According to conspiracy theories, the virus outbreak was the result of a biological warfare rather than a natural occurrence [10].
It should be noted that people who believe in and promote conspiracy theories on social media do not trust powerful groups who they consider to be withholding information, such as politicians and drug companies. If the public does not maintain trust in governmental organizations, they are less likely to follow any medical advice or procedures. Further, with the circulation of conspiracy theories, people may be more likely to develop negative attitudes toward and interpretations of preventive measures. They may even use dangerous alternatives as treatment, which will most likely increase the possibilities of the virus spreading and thus endangering more lives. Therefore, public attitude is extremely relevant to the current spread of conspiracy theories in relation to the COVID-19 outbreak. Alternative healing approaches to coronavirus are also being promoted among social media users. Some Twitter and Facebook users have claimed that the virus can be fought by drinking bleach products while others have called for a more herbal-based approach for protection. In some countries, calls for national Friday mass prayers have been circulated for protection from the virus [11].

It should be noted that conspiracy theories can be detrimental to social peace and harmony, as they can not only influence people's health choices but can also instigate xenophobia in societies, triggering violent social behavior [12]. The COVID-19 outbreak has led to a worldwide increase in discrimination and racist attacks targeted at people perceived as East Asian. The new \#JeNeSuisPasEnVirus (I'm not a virus) movement that spread in France is a clear example of this. It reflects the increasing frustration of French-Asian citizens who are experiencing a new form of stigma and discrimination due to this epidemic. This adverse phenomenon targets the Asian community, not just people of Chinese descent, and it is occurring both online and offline in the form of anti-Asian violence.

With the spread of the hashtag among Asian communities, the impact of conspiracy theories is becoming more evident. Online talk forums and discussions have implied that other world powers are targeting Asia, specifically China, to bring down its economy and weaken its global growth and expansion [13]. Although it has not yet been labeled as a pandemic by the WHO, COVID-19 has spread across the world. China's economy has already taken an enormous hit due to the COVID-19 outbreak. Exports from pharmaceuticals to cell phones have been declining, and manufacturing disruptions are causing massive supply chain problems worldwide. 
Therefore, are Intervening and Halting the Spread of Conspiracy Theories Related to COVID-19 Possible? In addition to taking prompt action to combat the spread of SARS-CoV2, governments need to step up their measures to prevent the spread of misinformation and conspiracy theories related to the virus. In doing so, fake news circulation can be significantly reduced. Heads of state, senior government officials, health and medical experts have taken to social media to reach out to vast audiences using platforms such as Twitter, Facebook, YouTube, and live streaming to disseminate relevant information and live updates. Over the past few years, since the emergence of SARS and MERS cases, the international community has made significant progress toward preparing for and mitigating the impacts of pandemics. The global community has realized the urgent need to collaborate to develop a unified global policy to detect, report, and respond to various outbreaks.

Sealing off nations or concealing information from the local and international community is not feasible anymore. Transparency and collective efforts will reform the shape and redefine the meaning of globalization again. Swift health policy action is also required to ensure sustainable health measures and preparedness globally. The upcoming years will most likely witness a surge in scholarly articles related to COVID-19 from the scientific, medical, and health fields; there shall also be an abundance of multidisciplinary research approaches and studies theorizing and analyzing this epidemic from various perspectives.

\section{References}

1. WHO (2020) Coronavirus? Geneva, Switzerland.

2. Zhang N, Wang L, Deng X, Liang R, Su M, et al. (2020) Recent advances in the detection of respiratory virus infection in humans. J Med Virol 92(4) 408-417.
3. Paules CL, Marston HD, Fauci AS (2020) Coronavirus Infections-More than just the common cold. JAMA.

4. Smith RD (2006) Responding to global infectious disease outbreaks: Lessons from SARS on the role of risk perception, communication and management. Soc Sci Med 63(12): 3113-3123.

5. SARS (2003) World Health Organization.

6. De Wit E, Doremalen VN, Falzarano D, Munster V J (2016) SARS and MERS: Recent insights into emerging coronaviruses. Nat Rev Microbiol 14(8): 523-534.

7. WHO (2020) Novel Coronavirus (2019-nCoV) Situation Report-3 p. 1-7.

8. Ruiz MA, Koutronas E (2020) The Networks Infection Contagious Diseases Positioning System (NICDP-System): The Case of WuhanCOVID-19 p. 1-14.

9. Heyer P (2003) America under attack: a reassessment of Orson Welles' 1938 war of the worlds broadcast. Canadian Journal of Communication 28(2): 149-165.

10. Millett P, Snyder BA (2017) Existential risk and cost-effective biosecurity. Health security 15(4): 373-383.

11. Matthews D A, Clark C (1999) The faith factor: Proof of the healing power of prayer. Penguin Random House, New York, USA.

12. Adam H, Moodley K (2013) Imagined liberation: Xenophobia, citizenship and identity in South Africa, Germany and Canada. African Sun Media 4.

13. Mearsheimer JJ (2014) Can China rise peacefully? The National Interest 25(1): 1-40. 